\title{
THE GENETIC RELATIONSHIP BETWEEN SOME STRAWBERRY CULTIVARS AND F1 POPULATION DERIVED FROM THESE CULTIVARS
}

\author{
OZTURK ERDEM, S.* - CEKIC, C. \\ Department of Horticulture, Faculty of Agriculture, Gaziosmanpasa University, Tokat, Turkey \\ (phone: +90-356-252-1616; fax: +90-356-252-1488 \\ *Corresponding author \\ e-mail: sozturkerdem@gmail.com; phone: +90-546-915-1453; fax: +90-356-252-1488 \\ (Received 22 $2^{\text {nd }}$ Feb 2018; accepted $10^{\text {th }}$ May 2018)
}

\begin{abstract}
In this study, while Osmanli strawberry, which has some superior characteristics like taste, aroma and male sterility that makes breeding studies easier, has been used as maternal parent, three local (Karacilek, Tuylu and Deli) cultivars in Turkey and three standard (Kabarla, Sweet Ann and Sweet Charlie) strawberry cultivars were used as paternal parents. Molecular analyses were conducted for determination of polymorphism levels by using 14 UBC-ISSR primers for the examination of $52 \mathrm{~F} 1$ genotypes that included selections as a result of hybridization studies, parents that were used in hybridization studies, and Fragaria chiloensis. 76 DNA bands were obtained in total and 60 of them were determined as polymorphic. The resulting data of the evaluation of ISSR-PCR bands, were analysed in Popgene32 and MEGA5.0 packaged software and the dendrogram was obtained according to the UPGMA method. The dendrogram was separated into two major groups at the $20 \%$ difference level, one is larger and the other is smaller. While Fragaria chiloensis, Tuylu-2 local cultivar, CC48 and CA97 F1 genotypes participated in the small group, the other F1 genotypes and parents participated in the larger group.
\end{abstract}

Keywords: hybridization breeding, ISSR, molecular, Osmanli cultivar, strawberry

\section{Introduction}

Strawberry is one of the rare fruit species that can be grown in large ecological zones, and it is known and grown in Turkey for a long time (Konarli, 1986). When the strawberry was classified botanically in the world, it was placed in Rosales family and Fragaria genus (Hancock and Luby, 1993). Most of strawberries that are grown commercially, belong Fragaria $x$ ananassa species that was derived from hybridization of two local American species (F. chiloensis X F. virginiana) (Hancock, 1999).

More than 20 strawberry species with different ploidy levels were identified. $F$. vesca and $F$. viridis $(2 \mathrm{n}=2 \mathrm{x}=14)$ are found as diploid species in the flora of Turkey. As well as these wild species, octoploid $F$. $\times$ ananassa were used for cultivation in Turkey for a long time, generating strawberry genetic resources. Osmanli and Arnavutkoy local cultivars were started to grown in limited areas because of cultivation of the new cultivars with higher quality and yield from another countries has become more common Osmanli cultivar that is known by its taste, colour and aroma, is only grown in a very small area in Eregli and Bartin regions in the West Black Sea Region of Turkey by few growers (Demirsoy and Serce, 2016). Dokuzoguz (1963) also reported that Eregli, Karsiyaka, and Kestel have specific characteristics comparing to the cultivars of Arnavutkoy, Eregli, Madame Moutot and Mangro, which are all called Osmanli or Arnavutkoy with small, oval-shaped, light-coloured fruits but have different other characteristics. 
Modern strawberry cultivation started in the 1960s in Turkey (Konarli and Philippe, 1968). Since the strawberry cultivation started, the main purpose is having a corner on the domestic and foreign market by doing high quality and early-grown cultivation. Besides the superior aromatic characteristics, profitable cultivation with local cultivars is not possible due to low yield, soft fruit flesh and small fruits. Although strawberry cultivars that is originated from another countries have earliness and high yield characteristics, they have middle level aromatic characteristics. Because of these reasons, breeding studies have being conducted that local cultivars have been used as parents since 1960. In the most of these studies, Osmanli strawberry, which have some superior characteristics (taste, aroma, the situation of fruit stalk, etc.) and male sterility that makes breeding studies easier, has been used as maternal parent (Kaska and Paydas, 1986; Ustun and Paydas, 1995; Paydas et al., 1996; Caglar and Paydas, 2002; Kiyga, 2009).

Modern breeding methods were developed especially after the beginning of the $20^{\text {th }}$ century. In the last 30 years, 38 cultivars in Turkey and more than 900 cultivars in the world have been developed and registered (Della Strada and Fideghelli, 2011; Chandler et al., 2012; Turemis and Agaoglu, 2013; Faedi and Baruzzi, 2016).

The knowledge about genetic structure is important, especially when it is worked with wild species (Ahmadi and Bringhurst, 1991). Morphological, physiological and cytological characteristics were used at the beginning for the determination of genetic variation, afterwards, biochemical markers were developed. Furthermore, molecular studies are conducted recently (Scarano et al., 2002).

Molecular markers are derived from the DNA in the cell of the plants. Thus, molecular markers are almost $100 \%$ reliable for the determination of the diversity between plant populations and plant genotypes. Today, molecular markers are used commonly in plant taxonomy studies, breeding and evaluation of genetic resources (Gulsen and Mutlu, 2005).

DNA markers are more preferred than isoenzyme, biochemical and morphological markers in the studies about the determination of species and cultivars. PCR based DNA markers; AFLP Amplified Fragment Length Polymorphism), CAPS (Cleaved Amplified Polymorphic Sequences), ISSR (Inter Simple Sequence Repeats), SSR (Simple Sequence Repeats) and RAPD (Random Amplified Polymorphic DNA) were used on many studies about strawberry (Tyrkal et al., 2002; Kunihisa et al., 2003, 2005; Kashyap et al., 2005; Bassil et al., 2006; Milella et al., 2006; Serce et al., 2007). While CAPS, RFLP and SSR are codominant, AFLP, ISSR and RAPD are dominant molecular markers (Kafkas, 2006).

In ISSR (Inter Simple Sequence Repeats) method, one primer is used and it has two, three and four sequence repeat on it. This method is used commonly in the determination of DNA fingerprint and genetic relationships (Cekic et al., 2001; Arnau et al., 2002; Kuras et al., 2004; Debnath et al., 2008; Nunes et al., 2013).

Arnau et al. (2002) scanned eighteen ISSR primers and selected five of them. They used those primers for characterization of genotypes of 30 different strawberry $(F . x$ ananassa L.) cultivars and they obtained 113 polymorphic bands.

Serçe et al. (2006) studied with 16 cultivars belong to $F$. chiloensis, $F$. virginiana and Fragaria $x$ ananassa, and Osmanli, Karacilek, Tuylu and Arnavutkoy local cultivars. Although Osmanli strawberry was morphologically similar with $F$. chiloensis clones, it was observed in the dendrogram obtained by 13 SSR primers that Osmanli, Karacilek, Tuylu and Arnavutkoy cultivars were different with the other three species 
and generated different group. Moreover, researchers suggested that more primers should be used with the purpose of obtaining more reliable results.

The aim of this study was the determination of genetic relationships by using ISSR markers between $52 \mathrm{~F} 1$ genotypes that were selected according to their superior morphological, pomological and physiological characteristics, parents that were used in hybridization studies, and Fragaria chiloensis within the scope of 'Osmanli Strawberry Breeding' project that is conducted in University of Gaziosmanpasa. Obtained data were evaluated according to the UPGMA dendrogram and Principal coordinate analysis

\section{Material and method}

\section{Material}

In this study, within the scope of 'Osmanli Strawberry Breeding' project that is conducted at the University of Gaziosmanpasa in Turkey, 52 selected F1 genotypes, the parents (Osmanli and eleven pollinators) as well as Fragaria chiloensis for comparision were used in molecular analysis.

In the hybridization programme, while Osmanli strawberry cultivar which is morphologically male sterile was used as maternal parent, 8 local genotypes ('Osmanli1', 'Osmanli-2', 'Osmanli-3', 'Osmanli-4', 'Tuylu-1', 'Tuylu-2', 'Karacilek-1', 'Karacilek-2') (Table 1), from Eregli district of Zonguldak province and 3 standard cultivars ('Kabarla', 'Sweet Ann' and 'Sweet Charlie') provided from private seedling companies were used as pollinators.

Table 1. Coordinates belongs to local parents, and names of F1 genotypes

\begin{tabular}{|c|c|c|c|c|c|}
\hline \multicolumn{6}{|c|}{ Local parent } \\
\hline & Sample Code (ID) & $\begin{array}{l}\text { Altitude } \\
\text { (m) }\end{array}$ & \multicolumn{2}{|l|}{ Latitude } & Longitude \\
\hline & Osmanli-1 & 220 & \multicolumn{2}{|l|}{$41^{\circ} 18.309 \mathrm{~K}$} & $031^{\circ} 26.666 \mathrm{D}$ \\
\hline & Osmanli-2 & 267 & \multicolumn{2}{|l|}{$41^{\circ} 18.528 \mathrm{~K}$} & $031^{\circ} 26.795 \mathrm{D}$ \\
\hline & Osmanli-3 & 237 & \multicolumn{2}{|l|}{$41^{\circ} 17.659 \mathrm{~K}$} & $031^{\circ} 28.026 \mathrm{D}$ \\
\hline & Osmanli-4 & 152 & \multicolumn{2}{|l|}{$41^{\circ} 16.919 \mathrm{~K}$} & $031^{\circ} 28.879 \mathrm{D}$ \\
\hline & Karacilek-1 & 220 & \multicolumn{2}{|l|}{$41^{\circ} 18.309 \mathrm{~K}$} & $031^{\circ} 26.666 \mathrm{D}$ \\
\hline & Karacilek-2 & 237 & \multicolumn{2}{|l|}{$41^{\circ} 17.659 \mathrm{~K}$} & $031^{\circ} 28.026 \mathrm{D}$ \\
\hline & Tuylu-1 & 237 & \multicolumn{2}{|l|}{$41^{\circ} 17.659 \mathrm{~K}$} & $031^{\circ} 28.026 \mathrm{D}$ \\
\hline & Tuylu-2 & 152 & \multicolumn{2}{|l|}{$41^{\circ} 16.919 \mathrm{~K}$} & $031^{\circ} 28.879 \mathrm{D}$ \\
\hline \multicolumn{6}{|c|}{ F1 genotypes } \\
\hline ID & Parents & ID & Parents & ID & Parents \\
\hline $\mathrm{CC}-4$ & Osmanli3XSweet Charlie & DB-118 & Osmanli4XKabarla & DC-63 & Osmanli4XSweet Charlie \\
\hline $\mathrm{CC}-35$ & Osmanli3XSweet Charlie & DB-119 & Osmanli4XKabarla & DC-104 & Osmanli4XSweet Charlie \\
\hline CC-42 & Osmanli3XSweet Charlie & DB-137 & Osmanli4XKabarla & DC-126 & Osmanli4XSweet Charlie \\
\hline CC-48 & Osmanli3XSweet Charlie & DA-1 & Osmanli4XSweet Ann & DC-136 & Osmanli4XSweet Charlie \\
\hline
\end{tabular}




\begin{tabular}{c|c|c|c|c|c} 
CC-60 & Osmanli3XSweet Charlie & DA-4 & Osmanli4XSweet Ann & CA-3 & Osmanli3XSweet Ann \\
CC-64 & Osmanli3XSweet Charlie & DA-6 & Osmanli4XSweet Ann & CA-15 & Osmanli3XSweet Ann \\
DB-7 & Osmanli4XKabarla & DA-9 & Osmanli4XSweet Ann & CA-23 & Osmanli3XSweet Ann \\
DB-15 & Osmanli4XKabarla & DA-40 & Osmanli4XSweet Ann & CA-87 & Osmanli3XSweet Ann \\
DB-35 & Osmanli4XKabarla & DA-61 & Osmanli4XSweet Ann & CA-97 & Osmanli3XSweet Ann \\
DB-41 & Osmanli4XKabarla & DA-87 & Osmanli4XSweet Ann & CB-26 & Osmanli3XKabarla \\
DB-48 & Osmanli4XKabarla & DA-88 & Osmanli4XSweet Ann & CB-86 & Osmanli3XKabarla \\
DB-49 & Osmanli4XKabarla & DA-95 & Osmanli4XSweet Ann & CK1-9 & Osmanli3XKaracilek1 \\
DB-57 & Osmanli4XKabarla & DC-7 & Osmanli4XSweet Charlie & CK1-33 & Osmanli3XKaracilek1 \\
DB-68 & Osmanli4XKabarla & DC-42 & Osmanli4XSweet Charlie & DK1-24 & Osmanli4XKaracilek1 \\
DB-73 & Osmanli4XKabarla & DC-44 & Osmanli4XSweet Charlie & CC-2 & Osmanli3XSweet Charlie \\
DB-88 & Osmanli4XKabarla & DC-54 & Osmanli4XSweet Charlie & CC-19 & Osmanli3XSweet Charlie \\
DB-97 & Osmanli4XKabarla & DC-60 & Osmanli4XSweet Charlie & DB-69 & Osmanli4XKabarla \\
DB-84 & Osmanli4XKabarla & & & \\
\hline
\end{tabular}

\section{Method}

\section{DNA isolation}

DNA isolation was done from $1.5-2 \mathrm{~cm}$ length young leaf samples from each genotype according to the Mini-CTAB method belongs to Doyle and Doyle (1987).

\section{PCR amplification}

ISSR method was used because generated bands are reproducible (reliability) and have high polymorphism (scorability), and also, scanning large number of different locus is possible (Prevost and Wilkinson, 1999; Cekic et al., 2001).

For the determination of polymorphism levels, 14 primers were used that were selected from 100 UBC primers, which was used for 'Fragaria vesca' before (Table 2) (Cekic et al., 2001). PCR method with constant annealing temperature that was used by Cekic et al. (2001) and Touchdown PCR method by Sargent et al. (2003) were modified and used. ISSR PCR reaction was done with $2 \mu \mathrm{L}$ DNA $(10 \mathrm{ng} / \mu \mathrm{L})$ and $23 \mu \mathrm{L}$ reaction composition [5 $\mu \mathrm{L}$ 10X PCR buffer solution, $2 \mu \mathrm{L} 25 \mathrm{mM} \mathrm{Mg}^{+2}, 1.25 \mu \mathrm{L} 2.5 \mathrm{mM}$ $\mathrm{dNTP}, 0.1 \mu \mathrm{L}$ Taq DNA Polymerase, $1 \mu \mathrm{L} 0.5 \mu \mathrm{M}$ primer and $13.65 \mu \mathrm{L}$ PCR water]. PCR products were separated in $100 \mathrm{~V}$ constant voltage during 2 hours by using $1 \mathrm{X}$ TBE buffer as a gelling agent and the electrode buffer solution, and $2 \%$ agarose gel for electrophoresis. Afterwards, DNA bands were imaged under ultraviolet lights.

\section{Data analyses}

Data, which were used in the statistical analyses, were obtained by the method that is about scoring one (1) when there was ISSR band and scoring zero (0) when there was not ISSR band. Similarities and differences between genotypes were determined in the molecular level. Principal Coordinates Analysis (PCoA) was done by similarity coefficient. Data were analysed in Popgene32 version 1.32 (Population Genetic 
Analysis) and MEGA 5.0 (Molecular Evolutionary Genetic Analysis) packaged software and the dendrogram was obtained according to the UPGMA (Unweighted Pair-

Group Method With Arithmetic Average) method (Parmaksiz and Ozcan, 2011). Furthermore, generating similarities/differences matrix between genotypes and Principal Coordinates Analysis (PCoA) were done by using NTSYS-pc ver. 2.10d (Numerical Taxonomy and Multivariate Analysis System) packaged software that was developed by Rohlf (2002).

Table 2. ISSR primers

\begin{tabular}{c|c|c|c|c|c}
\hline $\begin{array}{c}\text { Primer } \\
\text { name }\end{array}$ & $\mathbf{5}^{\prime}-\mathbf{3}$ ' sequence & $\begin{array}{c}\text { Degree of } \\
\text { dissociation } \\
\mathbf{( C )}\end{array}$ & $\begin{array}{c}\text { Primer } \\
\text { name }\end{array}$ & $\mathbf{5}^{\prime}-\mathbf{3}$ ' sequence & $\begin{array}{c}\text { Degree of } \\
\text { dissociation } \\
(\mathbf{C})\end{array}$ \\
\hline 807 & AGAGAGAGAGAGAGAGT & 50 & 888 & BDBCACACACACACACA & 52 \\
\hline 808 & AGAGAGAGAGAGAGAGC & 53 & 889 & DBDACACACACACACAC & 52 \\
\hline 810 & GAGAGAGAGAGAGAGAT & 50 & 890 & VHVGTGTGTGTGTGTGT & 52 \\
\hline 811 & GAGAGAGAGAGAGAGAC & 53 & 891 & HVHTGTGTGTGTGTGTG & 52 \\
\hline 835 & AGAGAGAGAGAGAGAGYC & 54 & 856 & ACACACACACACACACYA & 53 \\
\hline 841 & GAGAGAGAGAGAGAGAYC & 54 & 826 & ACACACACACACACACC & 52 \\
\hline 842 & GAGAGAGAGAGAGAGAYG & 55 & 844 & CTCTCTCTCTCTCTCTRC & 53 \\
\hline
\end{tabular}

\section{Results}

Some DNA bands were not clear may be due to PCR gel imaging system or ethidium bromide. Therefore, scoring studies were done with clear DNA bands. 76 DNA bands were determined at the end of the study and 60 of them were polymorphic. Band number obtained from primers varied between 3 and 8 , additionally, the average band number was 5.43 and the average polymorphic band number was 4.29. The highest band number was obtained from primer-810 ( 8 bands) and the lowest band number was obtained from primer-841 (3 bands). DNA bands, which were generated by primer- $835,841,844$ and 888 , were observed as polymorphic. The lowest polymorphism rate was determined on primer-842 with $50 \%$. The polymorphic band rate average was determined as $80.14 \%$ on 14 primers.

A dendrogram was obtained according to the UPGMA method (Fig. 1). The dendrogram was separated into two major groups at the $20 \%$ difference level, one is big and other is small. While Fragaria chiloensis, Tuylu-2 local cultivar, CC48 (Osmanl1-3 x Sweet Charlie) and CA97 (Osmanl1-3 x Sweet Ann) F1 genotypes participated in the small group, the other F1 genotypes and parents participated in the big group. It was observed that the big major group was separated again into groups with $17 \%$ level.

In this study, the highest similarity was determined between Osmanli-3 and Osmanli-4 with 3\%, and the second highest similarity was determined between Sweet Charlie and Kabarla. It was also observed that Osmanli-1, Osmanli-2 and Osmanli-3 were in the same subgroup.

It is known that Scatterplot PCo1 and PCo2 analyses support the results of the distribution of dendrogram (Ozyurt, 2011). In this study, it was determined that the distribution of genotypes on the Scatterplot (Fig. 2) obtained with Principal 
Coordinates Analysis (PCoA), showed similarity with distribution on the dendrogram (Fig. 1). 'Osmanli-1 (OsmA)', 'Karacilek-2 (Kara-C)', 'Tuylu-2 (Tuylu-D)', 'CA-97' and 'Fragaria chiloensis (FC)' were out of the high-density group according to Principal Coordinates Analysis 1 and 2. Furthermore, 'Karacilek-2 (Kara-C)', 'Tuylu-2 (Tuylu-D)', 'Sweet Charlie', 'Fragaria chiloensis (FC)', 'CC-48', 'CA-97' and 'DB-97' were out of the high-density group according to Principal Coordinates Analysis 1 and 3.

\section{Discussion and conclusion}

76 DNA bands were determined at the end of the study and 60 of them were polymorphic. Cao et al. (2000) stated that 50 polymorphic bands are sufficient to determine similarities and differences between genotypes successfully. It was observed that 60 obtained polymorphic bands are sufficient to work with. The polymorphic band rate average was determined as $80.14 \%$ on 14 primers. Arnau et al. (2002) used 5 ISSR primers on characterization of 30 different strawberry ( $F . x$ ananassa L.) genotypes and it was stated that 113 polymorphic bands were obtained.

Kuras et al. (2004) used ISSR and RAPD marker methods for determination of genetic relationships between 24 strawberry cultivars, which were obtained by breeding program conducted in Poland. Moreover, these two marker methods were compared in the same study. 41 of 90 ISSR primers and 23 of 48 RAPD primers were found as polymorphic. As a result of the UPGMA analyses, genetic relationships were determined and the family tree was generated. As a result of comparison of marker methods, ISSR was found better than RAPD in terms of genetic relationships.

The dendrogram obtained from genotypes was separated into two major groups, one is big and other is small, and the separation was done successfully with 14 ISSR primers. Debnath et al. (2008) determined genetic relationship of 27 strawberry cultivars by using 17 ISSR primers, and they obtained 225 polymorphic bands. The results were evaluated with UPGMA analysis, and it was stated that genetic relationship between cultivars varied between $63-77 \%$. 


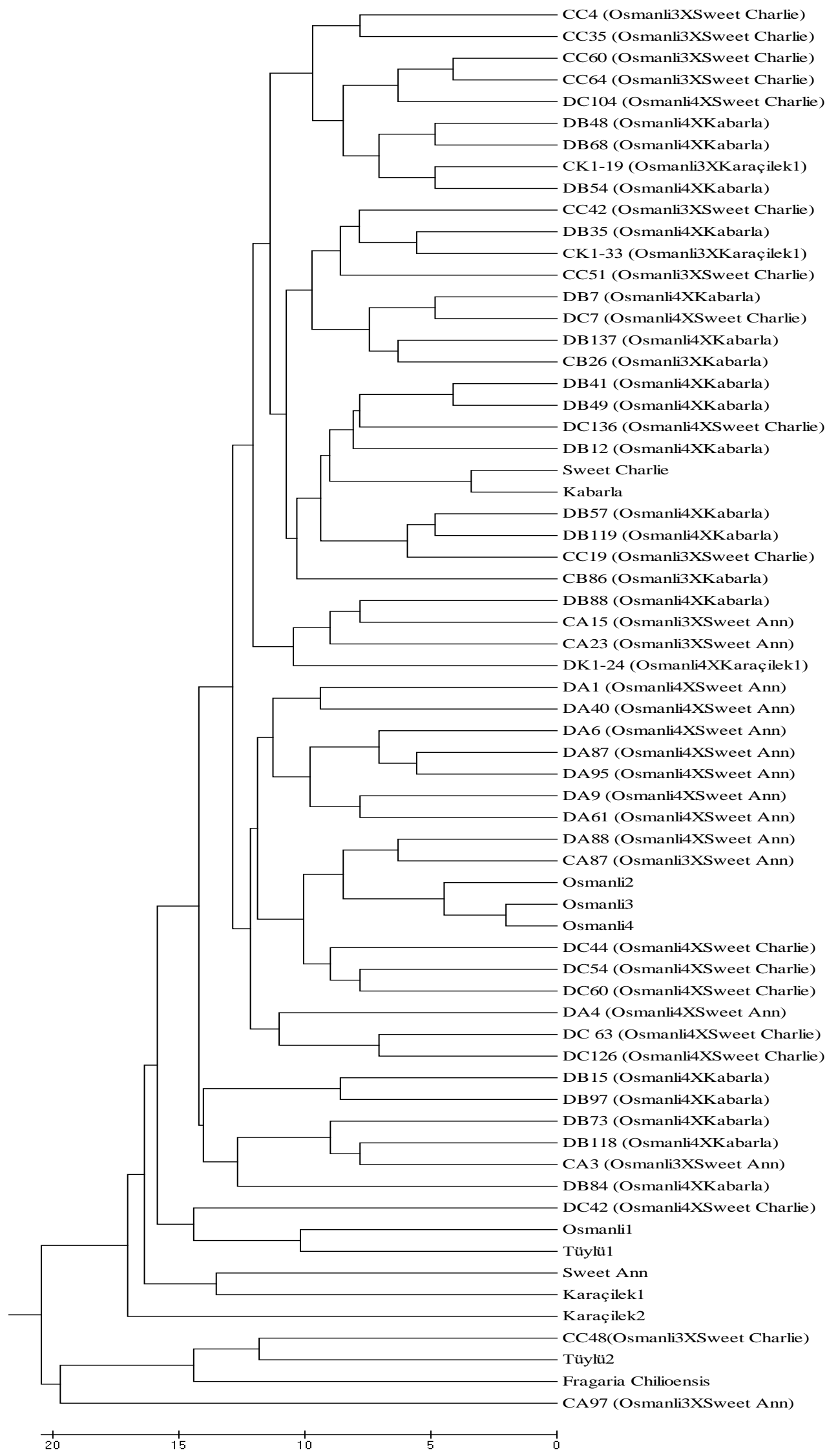

Figure 1. Dendrogram obtained with cluster analysis

APPLIED ECOLOGY AND ENVIRONMENTAL RESEARCH 16(3):2983-2993.

http://www.aloki.hu • ISSN 15891623 (Print) • ISSN 17850037 (Online)

DOI: http://dx.doi.org/10.15666/aeer/1603_29832993

(c) 2018, ALÖKI Kft., Budapest, Hungary 

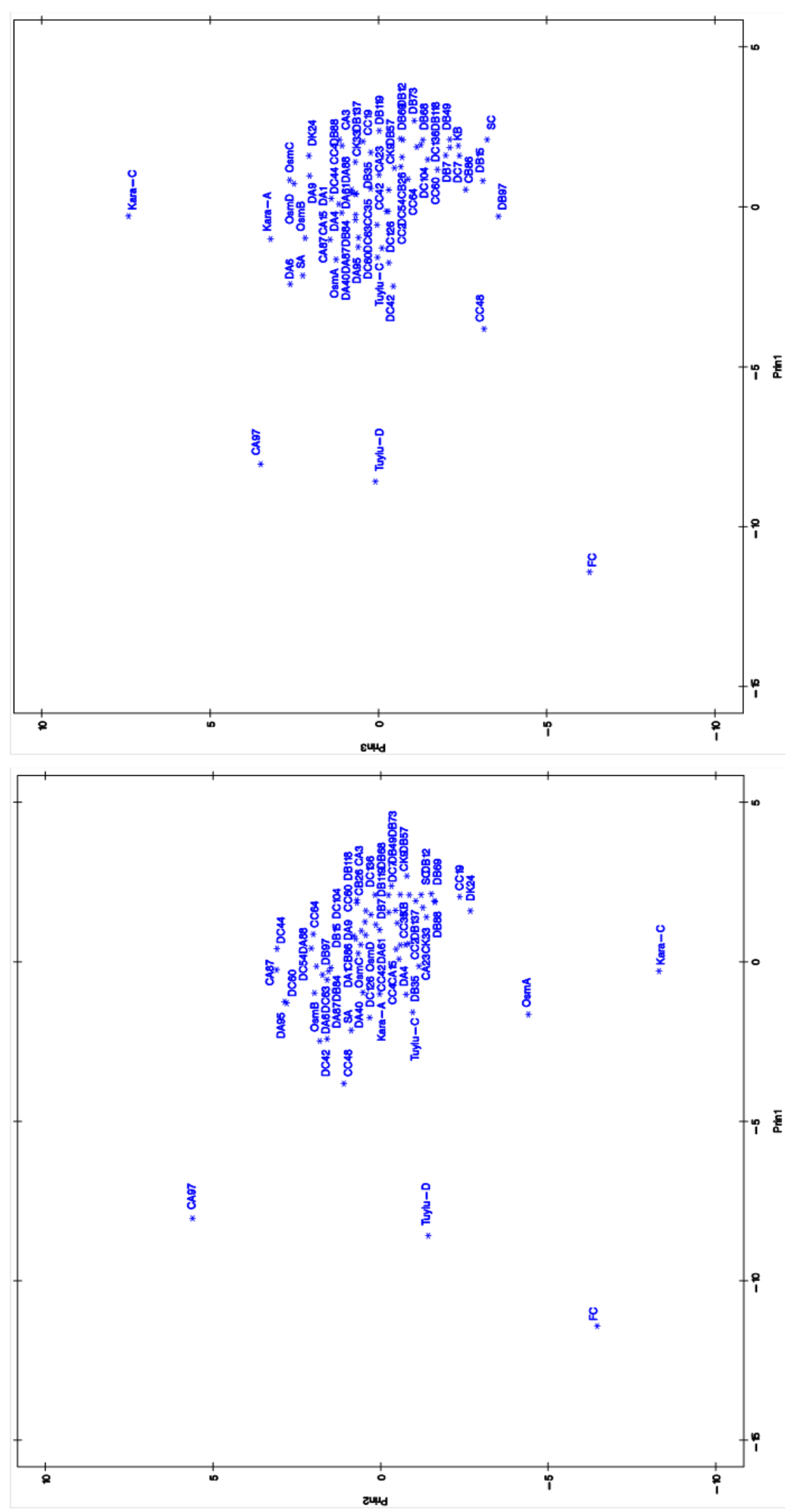

Figure 2. Scatterplot of PCo2 vs PCO1 and scatterplot of PCo3 vs PCO1 obtained by principal coordinate analysis

APPLIED ECOLOGY AND ENVIRONMENTAL RESEARCH 16(3):2983-2993.

http://www.aloki.hu • ISSN 15891623 (Print) • ISSN 17850037 (Online)

DOI: http://dx.doi.org/10.15666/aeer/1603_29832993

(c) 2018, ALÖKI Kft., Budapest, Hungary 
In the literature, it was stated that 'Osmanli' local cultivar and $F$. chiloensis show similarity, however, Tuylu-2 genotype and $F$. chiloensis showed similarity with $14.00 \%$ in this study. All the local genotypes were collected from Eregli district in Black Sea Region, also, it was observed that Tuylu and Osmanli local cultivars showed similarity in terms of fruit structure. F. chiloensis and Tuylu local cultivars were in the same group, thus, it is thought that Osmanli local cultivar changed by the time due to cross pollination.

Selected F1 genotypes will be used in the further studies leading to obtain new strawberry cultivars. Specific molecular markers could also be generated using these F1 genotypes.

Acknowledgements. This study was supported by 'TÜBİTAK 2211-C National PhD Fellowship Programme for Priority Areas' and 'University of Gaziosmanpasa BAP Commission Project-2015/54', which were produced from the thesis titled 'OSMANLI STRAWBERRY BREEDING-I'.

\section{REFERENCES}

[1] Ahmadi, H., Bringhurst, R. S. (1991): Genetics of sex expression in Fragaria species Amer. Journal of Botany 78: 504-514.

[2] Arnau, G., Lallemand, J., Bourgoin, M. (2002): Fast and reliable strawberry cultivar identification using inter simple sequence repeat (ISSR) amplification. - Euphytica 129: 69-79.

[3] Bassil, N. V., Gunn, M., Folta, K., Lewers, K. (2006): Microsatellite markers for fragaria from 'strawberry festival' expressed sequence tags. - Moleculer Ecology Notes 6: 473476.

[4] Caglar, H., Paydas, S. (2002): Changes of Quality Characteristics and Aroma Compounds of Hybrids and Some Strawberry cvs during Harvest Periods. - In: Hietaranta, T., Linna, M.-M., Palonen, P., Parikka, P. (eds.) Proceeding of the Fourth Int. Strawberry Symp. 815 July, 2000. Acta Hort. 567(1): 203-206.

[5] Cao, W., Scoles, G. J., Hucl, P., Chibbar, R. N. (2000): Phylogenetic relationships of five morphological groups of hexaploid wheat (Triticum Aestivum L. Em Thell) based on Rapd analysis. - Genome 43: 724-727.

[6] Cekic, C., Battey, N. H., Wilkinson, M. J. (2001): The potential of ISSR-PCR primer pair combinations for genetic linkage analysis using the seasonal flowering locus in Fragaria vesca as a model. - Theoretical and Applied Genetics 103(4): 540-546.

[7] Chandler, C. K., Folta, K., Dale, A., Whitaker, V. M., Herrington, M. (2012): Strawberry. - In: Badenes, M. L., Byrne, D. H. (eds.) Fruit Breeding, pp. 305-328. Springer, London.

[8] Debnath, S. C., Khanizadeh, S., Jamienson, A. R., Kempler, C. (2008): Inter Simple Sequence Repeat (ISSR) markers to assess genetic diversity and relatedness within strawberry genotypes. - Canadian Journal of Plant Science 88: 313-322.

[9] Della Strada, G., Fideghelli, C. (2011): The Fruit Varieties Released in the World from 1980 through 2008. - CRA-Centro Di Ricerca Per La Fruticolyura - Ministero Politiche Agricole E Forestali, Rome.

[10] Dokuzoğuz, M. (1963): Önemli Çilek Çeşitlerimiz Üzerinde Araştırmalar. - Journal of Agriculture Faculty of Ege University 74: 16-17.

[11] Doyle, J. J., Doyle, J. L. (1987): A rapid DNA isolation procedure for small quantities of fresh leaf tissue. - Phytochemical Bulletin 19: 11-15.

[12] Faedi, W., Baruzzi, G. (2016): Strawberry Breeding. - Husaini, A. M., Neri, D. (eds.) Strawberry: Growth, Development and Diseases, pp. 26-40. CABI, Wallingford, UK. 
[13] Gulsen, O., Mutlu, N. (2005): Genetic markers used in plant sciences and their utilization. - Alatarim 4(2): 27-37.

[14] Hancock, J. F. (1999): Strawberries. - Crop Production Science in Horticulture Series, No 11. CABI, Wallingford, UK.

[15] Hancock, J. F., Luby, J. J. (1993): Genetic resources at our door step: the wild strawberries. - Bioscience 43: 141-147.

[16] Kafkas, S. (2006): DNA Markörleri ve Bitki Islahında Kullanımı Kursu, 1-20 Ocak 2006. - Kurs notu (unpublished).

[17] Kashyap, S., Kaur, R., Sharma, D. R., Kumar, K., Sharma, S. K. (2005): Molecular characterization and genetic diversity in Fragaria genotypes as revealed by randomly amplified DNA polymorphisms (RAPDS). - ISHS Acta Horculturae 696(VII): 135-142 (International Symposium on Temperate Zone Fruits in the Tropics and Subtropics - Part Two).

[18] Kaska, N., Paydas, S. (1986): Çilek Melezleri Üzerine Çalışmalar [in Turkish]. - The Scientific and Technological Research Council Of Turkey (TOAG). - Bitki Islahı Simpozyumu. 15-17 Ekim 1986, İzmir.

[19] Kiyga, Y. (2009): Morphological and Pomological Characterizations of Osmanli X Camarosa Strawberry Hybrids. - Master Thesis. Mustafa Kemal University Graduate School of Natural and Applied Sciences, Antakya.

[20] Konarli, O. (1986): Ülkesel Üzümsü Meyveler Araştırma Projesi 1985 Y11ı Koordinatör Raporu (in Turkish). - Ataturk Horticultural Central Research Institute, Yalova.

[21] Konarli, O., Philippe, J. M. (1968): Çilek Çeşit Denemesi (in Turkish). - Journal of Yalova Horticultural Research Institute 1(3): 26-32.

[22] Kunihisa, M., Fukino, F., Matsumoto, S. (2003): Development of cleavage amplified polymorphic sequence (CAPS) markers for identification of strawberry cultivars. Euphytica 134: 209-215.

[23] Kunihisa, M., Fukıno, F., Matsumoto, S. (2005): CAPS markers improved by clusterspecific amplification for identification of octoploid strawberry (Fragaria $x$ ananassa Duch.) Cultivars, and their disomic inheritance. - Theoretical and Applied Genetics 110: 1410-1418.

[24] Kuras, A., Korbin, M., Zurawicz, E. (2004): Comparison of suitability of RAPD and ISSR techniques for determination of strawberry (Fragaria $x$ ananassa Duch.) relationship. - Plant Cell, Tissue and Organ Culture 79: 189-194.

[25] Milella, L., Saluzzi, D., Lapelosa, M., Bertino, G., Spada, P., Greco, I., Martelli, G. (2006): Relationships between an italian strawberry ecotype and its ancestor using RAPD markers. - Genetic Resources and Crop Evaluation 53: 1715-1720.

[26] Nunes, C. F., Ferreira, J. L., Generoso, A. L., Carvalho, M. S., Pasqual, M., Almeida Cancado, G. M. (2013): The genetic diversity of strawberry (Fragaria ananassa Duch.) hybrids based on ISSR markers. - Acta Scientiarum 35(4): 443-452.

[27] Ozyurt, I. K. (2011): Clonal selection in Prunus mahaleb L. rootstock with drought resistant. - Doctorate Thesis. University of Gaziosmanpasa, Tokat.

[28] Parmaksiz, I., Ozcan, S. (2011): Morphological, chemical, and molecular analyses of Turkish Papaver accessions (Sect. Oxytona). - Turk J Bot 35: 1-16.

[29] Paydas, S., Kaska, N., Caglar, H., Yas, E. (1996): Investigations on the Yield, Fruit Quality and Aroma Compounds of Some Strawberry Cultivars and Hybrids. - Proceeding of the First Egyptian-Hungarian Horticultural Conference, 15-17 September, Kafr ElSheikh_Egypt, pp. 172-177.

[30] Prevost, A., Wilkinson, M. J. (1999): A New system of comparing PCR primers applied to ISSR fingerprinting of potato cultivars. - Theoretical and Applied Genetics 98: 107112.

[31] Rohlf, F. J. (2002): NTSYSpc: Numerical Taxonomy and Multivariate Analysis System Version 2.1. - Exeter Software, Setauket, New York. 
[32] Sargent, D. J., Hadonou, A, M., Simpson, D, W. (2003): Development and characterisation of polymorphic microsatellite markers from Fragaria viridis, a wild diploid strawberry. - Mol Ecol Notes 3: 550-552.

[33] Scarano, M. T., Abbate, L., Ferrante, S., Lucretti, S., Tusa, N. (2002): ISSR-PCR technique: a useful method for characterizing new allotetraploid somatic hybrids of mandarin. - Plant Cell Reports 20: 1162-1166.

[34] Serce, S., Paydas, S., Kaska, N., Gunduz, K., Ozdemir, E., Hancock, J. F., Makaraci, Z. (2007): Türkiye'deki Mevcut Çilek (Fragaria sp.) Gen Kaynaklarının Toplanarak Değerlendirilmesi ve Çekirdek Koleksiyonlarının Oluşturulması (in Turkish). - The Scientific and Technological Research Council of Turkey (TOVAG 103O121).

[35] Turemis, N., Agaoglu, Y. S. (2013): Çilek (in Turkish). - Ağaoğlu, S., Gerçekcioğlu, R. (eds.) Üzümsü Meyveler, pp. 57-120. Tomurcukbağ Ltd. Şti. Eğitim Yayınları, No: 1, Ankara.

[36] Tyrkal, M., Dziadczyk, P., Hortiyonsk1, A. (2002): Simplified AFLP procedure as a tool for identification of strawberry cultivars and advanced breeding lines. - Euphytica 125: 273-280.

[37] Ustun, P., Paydas, S. (1995): Bazı Melez Çilek Çeşit Adaylarının Verim ve Kalitesi Üzerinde Araştırmalar (in Turkish). - Türkiye II. Ulusal Bahçe Bitkileri Kongresi 301305. 